\title{
REPLACEMENT CORN SILAGE BY ORANGE WASTE SILAGE IN BARKI RAM LAMBS RATIONS
}

\author{
A. A. Mahrous' ${ }^{1}$; A. S. Karkoutlii ${ }^{2}$ A. A. H. El-Tahan ${ }^{1}$; Y. H. Hafez ${ }^{1}$; A. A. Abu El-Alla ${ }^{1}$ and \\ S. K. Moussa ${ }^{2}$ \\ ${ }^{1}$ Animal Production Research Institute, Agricultural Research Center, Dokki, Giza, Egypt. \\ ${ }^{2}$ The Arab Center for the Studies of Arid Zones and Dry Lands, ACSAD, Damascus, Syria.
}

\section{SUMMARY}

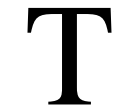

The present work was conducted to study the effect of replacement corn silage (CS) by orange waste silage (OR) improved the performance of Barki lambs using one of the following rations: R1: $50 \%$ concentrate feed mixture $(\mathrm{CFM})+40 \%$ corn silage $(\mathrm{CS})+10 \%$ rice straw (RS) (control). R2: $50 \%$ $\mathrm{CFM}+20 \% \mathrm{CS}+20 \%$ orange waste silage (OS) $+10 \% \mathrm{RS}$ and R3: $50 \% \mathrm{CFM}+40 \%$ OS $+10 \%$ RS. Two experimental trials were conducted: Results showed the silages had good smell and were free from any signs of molds in all groups. Digestibility trial was conducted using nine mature local Barki breed rams were divided in three groups ( 3 animals each) weighting with average body weight $57 \mathrm{~kg} \pm 1.5 \mathrm{~kg}$ and 3 years old. R3 recorded $(\mathrm{P}<0.05)$ the highest digestibility coefficients for all nutrients and nutritive value than others and the results showed a significant improvement $(\mathrm{P}<0.05)$ in digestibility coefficients of NDF, ADF and cellulose in R3 than others. Results showed insignificant differences $(\mathrm{P}>0.05)$ among the three tested groups in all blood parameters. Eighteen Barki lambs with average body weight $21.00 \pm 0.20 \mathrm{~kg} / \mathrm{head}$ were used. Lambs were divided into three groups ( 6 animals each) and fed the three respective rations with the same regime of feeding the experimental lasted for month. R3 recorded the highest value of average daily gain compared with R2 and R1. Also, R3 recorded the best value of feed conversion (6.24) followed by the R2 (6.52) than the control (7.03). It was concluded that corn silage by orange waste silage to rations of growing Barki lambs could improve their performance especially replacement of $100 \%$ corn silage by orange waste silage (R3).

Keywords: corn silage, orange waste silage, digestibility, blood parameters, Barki lambs, growth.

\section{INTRODUCTION}

In Egypt, the key limiting factor in animal production is considerably due to the high cost of formulating livestock rations along the year as there is a kind of completion between human and livestock for the conventional feedstuffs like corn grains as a main source of energy. Therefore it is necessary to being search currently for feed resources that are inexpensive and available and does not directly required as component of human diet and can economically considering as a vital ingredients in the rations of farm animals (Qelurem et al., 2007). The utilization of agricultural by-products and industrial residues in ruminant feed, looking to attenuate troubles of forage shortage and the reduction of the cost of animal feed during critical season. Citrus pulp is a by-product derived from the citrus juice industry and includes a mixture of citrus peel, pulp and seeds (Lanza, 1984). There are a lot of agro- industrial by- products which could be using potentially to replace corn grains and the other traditional feedstuffs (Shoukry et al., 1986). Dried orange pulp (DOP) or citrus pulp could be used effectively as an alternative energy source in replacement of some grains as corn, barley and other concentrated ingredients (Gado et al., 2011). The use of by-products for livestock feeding allows us to convert material that has limited application for use as human food into animal protein; ruminants are fundamental elements in that process. Citrus pulp is a by-product feed obtained during the manufacture of orange juice and processing of other citrus fruits (Grasse et al., 1995). The aim of this study is to find out the influence of feeding Barki lambs on different levels of replacement corn silage by orange waste silage on their nutrients digestibility, feeding value, rumen fermentation, sheep performance and their feed economic efficiency. 


\section{MATERIALS AND METHODS}

The experimental work of this study was carried out at El-Gemeza Experimental Station, Animal Production Research Institute, Agriculture Research Center. Eighteen Barki lambs at four months of age with an average live body weight $21 \pm 0.2 \mathrm{~kg}$ were assigned to three groups according to live body weight (6 lambs for each) in growth feeding trial (60 days) and received the following rations (Table, 2)

$$
\begin{aligned}
& \text { R1: } 50 \% \text { CFM + } 40 \% \mathrm{CS}+10 \% \mathrm{RS} \text { (control). } \\
& \text { R2: } 50 \% \mathrm{CFM}+20 \% \mathrm{CS}+20 \% \mathrm{OS}+10 \% \mathrm{RS} \\
& \text { R3: } 50 \% \mathrm{CFM}+40 \% \mathrm{OS}+10 \% \mathrm{RS} .
\end{aligned}
$$

Animals were groups fed according to NRC (1985). The chemical analyses of all feedstuffs were shown in Table (1).

Table (1): Chemical composition (\% on DM basis) of corn silage (CS), orange waste silage (OS), rice straw (RS) and concentrate feed mixture (CFM).

\begin{tabular}{lcccc}
\hline Item & CS & OS & RS & CFM* \\
\hline DM & 36.24 & 38.9 & 89.22 & 88.7 \\
OM & 86.90 & 83.95 & 83.75 & 92.82 \\
CP & 9.15 & 8.72 & 3.86 & 14.16 \\
CF & 24.67 & 28.56 & 36.70 & 11.05 \\
EE & 2.56 & 3.08 & 1.75 & 2.30 \\
NFE & 50.52 & 43.59 & 41.44 & 65.31 \\
Ash & 13.10 & 16.05 & 16.25 & 7.18 \\
NDF & 35.62 & 33.96 & 74.2 & 27.79 \\
ADF & 26.14 & 23.81 & 40.31 & 8.86 \\
ADL & 5.02 & 4.77 & 8.5 & 2.89 \\
Cellulose & 21.21 & 19.04 & 31.81 & 5.88 \\
Hemicelluloses & 9.48 & 10.15 & 33.89 & 18.89 \\
\hline$*$ Concentrate feed mixture (CFM) consisted of: 38\% ground yellow corn, 22\% undecorticated cotton seed meal, $7 \%$ \\
soybean meal, 12\% wheat bran, 13\% rice bran, 5\% cane molasses, 2\% lime stone and 1\% common salt.
\end{tabular}

Table (2): Calculated chemical composition of the experimental rations.

\begin{tabular}{lccc}
\hline \multirow{2}{*}{ Item } & \multicolumn{3}{c}{ Experimental rations } \\
\cline { 2 - 4 } & $\mathrm{R} 1$ & $\mathrm{R} 2$ & $\mathrm{R} 3$ \\
\hline $\mathrm{DM}$ & 67.77 & 68.30 & 68.83 \\
$\mathrm{OM}$ & 89.55 & 88.95 & 88.37 \\
$\mathrm{CP}$ & 11.13 & 11.04 & 10.95 \\
$\mathrm{CF}$ & 19.06 & 19.84 & 20.62 \\
$\mathrm{EE}$ & 2.35 & 2.45 & 2.56 \\
NFE & 57.01 & 55.62 & 54.24 \\
Ash & 10.45 & 11.05 & 11.63 \\
NDF & 35.56 & 35.23 & 34.90 \\
ADF & 18.92 & 18.45 & 17.99 \\
ADL & 4.30 & 4.25 & 4.20 \\
Cellulose & 14.61 & 14.17 & 13.74 \\
Hemicelluloses & 16.63 & 16.76 & 16.89 \\
\hline
\end{tabular}

Orange waste silage was prepared by collection of the orange (orange waste unfit for human consumption) from Edffina canning factory in Alexandria Governorate. One underground trenches (6 ton each) were fill for each) diet averaged $(57 \pm 1.50 \mathrm{~kg}$, a live body weight) and 3 years old. Animals were housed in individual metabolic cages for 21 days (14 days as a preliminary period followed by 7 days as 
collection period) to determine the digestibility coefficients and nutritive values of the three respective tested rations. Feces were collected quantitatively every day and $10 \%$ daily sample was taken and sprayed with $10 \%$ sulfuric acid and dried during the collection period. At the end of the collection period, feces samples for each ram were ground mixed well and kept in the refrigerator for chemical analysis. Rumen liquor samples were taken from each animal at the end of collection period by stomach tube at $4 \mathrm{hrs}$. post-feeding. The Ruminal $\mathrm{pH}$ values were measured immediately by $\mathrm{pH}$ meter. Ammonia nitrogen $\left(\mathrm{NH}_{3}-\mathrm{N}\right)$ concentration was measured according to Conway and O'Mally (1957). Total VFA's concentration was determined by the steam distillation method according to Abou-Akkada and Osman (1967). Total fungal counts were determined according to (Difco, 1984) and microbial protein was measured by sodium tangistate methods according to Shultz and Shultz (1970). Chemical analyses of feedstuffs and feces were carried out according to the A.O.A.C (1995). The nitrogen free extract (NFE) was calculated by subtracting the summation percentages of $\mathrm{CP}, \mathrm{CF}, \mathrm{EE}$ and Ash contents from one hundred. Neutral detergent fiber (NDF), acid detergent fiber (ADF) and acid detergent lignin (ADL) were determined by the methods of Van Soest $e t$ al. (1991). Blood samples were taken at the end of the experimental period. Blood samples were taken from the Jugular vein of three animals in each group at 8.00 am into vacationer tubes, and then allow the coagulated blood samples were centrifuged at $3000 \mathrm{rpm}$ for $20 \mathrm{~min}$ to obtain blood serum. The supernatant was frozen and stored at $-20^{\circ} \mathrm{C}$ for subsequent analysis. Blood serum was analyzed for total protein (Armstrong and Carr 1964), albumin (Doumas et al., 1971), globulin calculated by subtracting concentration of serum albumin from the corresponding concentration of total protein, creatinine (Folin, 1994), urea (Siest et al., 1981), cholesterol (Fassati and Prenciple, 1982) and triglycerides (Richmond, 1973) as well as activity of asprtate (AST) and alanine (ALT) aminotransaminases (Reitman and Frankel, 1957) and total antioxidant capacity (Sies, 1997) was estimated using commercial kits by calorimetric determination.

Collected data of silage characteristics, nutrients digestibilities, rumen fermentation and blood biochemical parameters were subjected to statistical analysis using one-way-analysis of variance according to Snedecor and Cochran (1980) was using the following mathematical model:

$$
\mathrm{Y}_{\mathrm{ij}}=\mu+\mathrm{T}_{\mathrm{i}}+\mathrm{e}_{\mathrm{ij}}
$$

Where: $Y_{i j}$ is the parameter under analysis, $\mu$ is the overall mean, $T_{i}$ is the effect due to treatment and $e_{i j}$ is the experimental error. The general linear model of SAS (2004) program was used in processing measured parameters. The difference between means was statistically measured for significance at $(\mathrm{P}<0.05)$ according to Duncan's test (1955)

\section{RESULTS AND DUSCUSSION}

\section{Silage characteristics:}

Fermentation characteristics of all silages during the ensiling period indicated a successful processing (Table, 3). Silages had good smell and were free from any signs of molds. Values of $\mathrm{pH}$ indicated good preserved silage as it decreased with advancing ensilaging period where it reached 3.79 and 4.20 at 8 weeks for corn silage and orange waste silage, respectively, which seems to be within the normal range for good quality silage as reported by McDonald et al. (1995). Data of fermentation characteristics are in agreement with previous studies reported by Sun et al., (2009). The differences in the concentrations of total organic acids among the two types of silages were significant $(\mathrm{P}<0.05)$ and ranged between 5.84 to $7.94 \%$ in all type of silage. These results are in agreement with those obtained by Shaver et al., (1985). Total VFA's concentration in two kinds of silages appeared to be within the normal range (1.45 to 1.67) for good quality silage which indicated acceptable silage fermentation. Also, low values for $\mathrm{NH}_{3}-\mathrm{N}$ concentration $(0.03$ to $0.05 \%$ of DM) over the two kinds of silage were obtained in present study and these results are matched with those recorded by Sheperd and Kung (1996). The changes in $\mathrm{NH}_{3}-\mathrm{N}$ values indicated less rate of soluble protein (SP) content, solubilization of true protein occurs in the silo due to the action of plant proteases enzymes. 
Table (3): Chemical characteristics of different corn silage and orange waste silage.

\begin{tabular}{llll}
\hline Item & CS & OS & \pm SE \\
\hline pH & $3.79^{\mathrm{b}}$ & $4.20^{\mathrm{a}}$ & 0.25 \\
Total organic acids\% of DM & $5.84^{\mathrm{b}}$ & $7.94^{\mathrm{a}}$ & 0.87 \\
TVFA s \% of DM & $1.45^{\mathrm{b}}$ & $1.67^{\mathrm{a}}$ & 0.65 \\
$\mathrm{NH}_{3}$-N\% of DM & $0.03^{\mathrm{b}}$ & $0.05^{\mathrm{a}}$ & 0.34 \\
\hline
\end{tabular}

${ }^{a}$ and ${ }^{b}$ Means in the same row with different superscript are significantly $(P<0.05)$.

\section{Digestibility coefficients and nutritive values:}

Data of Table (4) clearly indicated that animals fed R3 recorded the highest digestibility values of DM, OM, $\mathrm{CP}, \mathrm{CF}, \mathrm{EE}, \mathrm{NFE}$ and nutritive values as (TDN and DCP) compared with other rations. Results indicated that replacement corn silage by orange waste silage at $100 \%$ in ration $\mathrm{R} 3$ had significant $(\mathrm{P}<0.05)$ effect on all nutrient digestibility coefficients compared with control ration ( $\mathrm{R} !)$. These results are in agreement with those obtained by Gholizadeh and Naserian. (2010) and Shdaifat et al. ( 2013) who reported that DM and $\mathrm{OM}$ digestibilities tended to remain affected, $\mathrm{CP}$ digestibility was increased and crude fiber fractions (NDF and ADF) digestibility were increased when dried citrus pulp substitute for starchy feeds. Also on earlier study, Ben-Ghedalia et al. (1989) noticed that CP was more digestible in the starch- rich diet (barely) and NDF was more digestible in the pectin -rich diet (dry citrus pulp) in the concentrate diet, while OM equally digested in both diets. Recently Gawad et al. (2013) reported that DM, OM and CP digestibilities remained affected by various levels of dried citrus pulp. The high values of TDN and DCP of ration R3 contained orange waste silage may be attributed to the mutual associative effect of highest nutrients digestibility. These results are in accordance with those obtained by Taie et al., (1998); Etman et al. (2007) and Mostafa et al., (2010).

Table (4): Nutrients digestibility and nutritive values of experimental rations by Barki lambs.

\begin{tabular}{|c|c|c|c|c|}
\hline \multirow{2}{*}{ Item } & \multicolumn{3}{|c|}{ Experimental ration } & \multirow[b]{2}{*}{$\pm \mathrm{SE}$} \\
\hline & R1 & $\mathrm{R} 2$ & R3 & \\
\hline \multicolumn{5}{|c|}{ Digestibility coefficients\%: } \\
\hline $\mathrm{DM}$ & $63.82^{\mathrm{b}}$ & $63.78^{\mathrm{b}}$ & $65.98^{\mathrm{a}}$ & 0.50 \\
\hline $\mathrm{OM}$ & $60.73^{\mathrm{b}}$ & $60.53^{\mathrm{b}}$ & $64.77^{\mathrm{a}}$ & 0.02 \\
\hline $\mathrm{CP}$ & $66.43^{\mathrm{b}}$ & $66.60^{\mathrm{b}}$ & $69.04^{\mathrm{a}}$ & 0.78 \\
\hline $\mathrm{CF}$ & $62.82^{\mathrm{b}}$ & $63.00^{\mathrm{b}}$ & $65.96^{\mathrm{a}}$ & 0.54 \\
\hline $\mathrm{EE}$ & $73.40^{\mathrm{b}}$ & $73.04^{\mathrm{b}}$ & $76.40^{\mathrm{a}}$ & 0.60 \\
\hline NFE & $65.08^{\mathrm{b}}$ & $65.00^{\mathrm{b}}$ & $67.70^{\mathrm{a}}$ & 0.34 \\
\hline \multicolumn{5}{|c|}{ Cell wall constituents $\%$ : } \\
\hline $\mathrm{NDF}$ & $60.98^{\mathrm{b}}$ & $60.40^{\mathrm{b}}$ & $63.70^{\mathrm{a}}$ & 0.44 \\
\hline $\mathrm{ADF}$ & $52.33^{\mathrm{b}}$ & $52.43^{\mathrm{b}}$ & $54.60^{\mathrm{a}}$ & 0.87 \\
\hline ADL & $40.62^{\mathrm{b}}$ & $40.82^{\mathrm{b}}$ & $44.75^{\mathrm{a}}$ & 0.67 \\
\hline Cellulose & $20.48^{\mathrm{b}}$ & $20.55^{\mathrm{b}}$ & $22.62^{\mathrm{a}}$ & 0.54 \\
\hline Hemicellulose & $50.93^{\mathrm{b}}$ & $50.89^{\mathrm{b}}$ & $55.72^{\mathrm{a}}$ & \\
\hline \multicolumn{5}{|c|}{ Nutritive value $\%$ : } \\
\hline TDN & $60.06^{\mathrm{b}}$ & $60.09^{\mathrm{b}}$ & $62.52^{\mathrm{a}}$ & 0.43 \\
\hline $\mathrm{DCP}$ & $6.73^{\mathrm{b}}$ & $6.65^{\mathrm{b}}$ & $8.20^{\mathrm{a}}$ & 0.02 \\
\hline
\end{tabular}

\section{Total fungal counts and microbial protein:}

As shown in Table (5), R2 and R3 were found to achieve $(\mathrm{P}<0.05)$ higher total fugal count compared with R1. Significance increase in microbial protein was noticed in favor of groups fed orange waste silage being $\left(0.94\right.$ and $0.74\left(\times 10^{3} \mathrm{cfu} / \mathrm{ml}\right)$ for $\mathrm{R} 3$ and $\mathrm{R} 2$, respectively, compared with the control $\left(0.54 \times 10^{3}\right.$ $\mathrm{cfu} / \mathrm{m} 1)$. The microorganisms used most of the fermentable sugars from the protein for protein synthesis. Whereas the white rot fungi-exhibited promising ability for the decomposition of lignin-cellulose containing 
materials and for increasing the availability of carbohydrates and production of fungal protein Iconomou et al., (1997) and Philip et al., (2014).

Table (5): Total fungal counts and microbial protein for animals fed the experimental rations.

\begin{tabular}{lcccc}
\hline Item & \multicolumn{3}{c}{ Experimental ration } & \multirow{2}{*}{ \pm SE } \\
\cline { 2 - 4 } & $\mathrm{R} 1$ & $\mathrm{R} 2$ & $\mathrm{R} 3$ & 0.30 \\
\hline Total fungus Counts $\left(\times 10^{3} \mathrm{cfu} / \mathrm{ml}\right)$ & $1.60^{\mathrm{c}}$ & $1.83^{\mathrm{b}}$ & $1.99^{\mathrm{a}}$ & 0.40 \\
Microbial protein $(\mathrm{g} / 100 \mathrm{ml})$ & $0.54^{\mathrm{c}}$ & $0.74^{\mathrm{b}}$ & $0.94^{\mathrm{a}}$ & $0.05)$. \\
\hline${ }^{\mathrm{b}, b}$ and $^{\mathrm{c}}$ Means within the same row with different superscripts differ $(P<0.05)$.
\end{tabular}

\section{Blood serum parameters:}

The data of Table (6) sho as an antioxidant (Kleczkowski et al., 2004). wed insignificant (P>0.05) differences among the different experimental rations for blood serum urea, total protein, albumin, globulin, creatinine, urea, AST, ALT, cholesterol and triglyceride. Similar results were recognized by Allam et al. (2011) who showed that no significant differences in respect all blood parameters among rations contained different levels of dried orange pulp with lambs. All blood serum parameters were found to be within normal range as reported by Gholizadeh and Naserian (2010). Otherwise total antioxidants capacity concentration were the highest significantly $(\mathrm{P}<0.05)$ in $\mathrm{R} 3$ compared with others rations being $0.59,0.76$ and 0.97 (mmol/l) for R1, R2 and R3, respectively. Peroxidase is the most important enzymatic mechanisms which protect an organism against oxidative stress which safely interact with free radicals

Table (6): Effect of biological and chemical treatments on blood serum parameters for lambs.

\begin{tabular}{lcccc}
\hline Item & \multicolumn{3}{c}{ Experimental ration } & \multirow{2}{*}{ \pm SE } \\
\cline { 2 - 4 } & $\mathrm{R} 1$ & $\mathrm{R} 2$ & $\mathrm{R} 3$ & 0.33 \\
Total protein $(\mathrm{g} / \mathrm{dl})$ & 6.74 & 6.97 & 6.83 & 0.07 \\
Albumin $(\mathrm{g} / \mathrm{dl})$ & 3.89 & 3.97 & 3.91 & 0.29 \\
Globulin $(\mathrm{g} / \mathrm{dl})$ & 2.86 & 3 & 2.92 & 0.15 \\
Creatinine $(\mathrm{mg} / \mathrm{dl})$ & 0.86 & 0.86 & 0.82 & 3.67 \\
Urea $(\mathrm{mg} / \mathrm{dl})$ & 44.24 & 39.24 & 40.46 & 3.11 \\
ALT $(\mathrm{U} / \mathrm{ml})$ & 20.8 & 20 & 18 & 4.26 \\
AST $(\mathrm{U} / \mathrm{ml})$ & 37.2 & 34 & 35 & 0.05 \\
Total antioxidants & $0.59^{\mathrm{c}}$ & $0.76^{\mathrm{b}}$ & $0.97^{\mathrm{a}}$ & 5.25 \\
capacity $(\mathrm{mmol} / \mathrm{l})$ & & & 133.6 & 3.45 \\
Cholesterol $(\mathrm{mg} / \mathrm{dl})$ & 128.2 & 135.4 & 104 & \\
Triglycerides $(\mathrm{mg} / \mathrm{dl})$ & 111.8 & 107.4 & & 3 \\
\hline
\end{tabular}

${ }^{a}$ and ${ }^{b}$ Means within the same row with different superscripts differ $(P<0.05)$.

\section{Growth performance and economic efficiency:}

The average values of feed intake, daily gain, feed conversion and economic efficiency are shown in Table (7). Data revealed that total body gain and daily gain were increased for lambs fed rations containing orange waste silage. These results may be related the increasing digestibility coefficients for R3 and R2. The highest value of DMI was observed in R3 followed by R2. Bueno et al. (2002) replaced corn with dehydrated citrus pulp (DCP) at levels 0, 33, 66, 100\% in Saanen kid diets. They noted that, feed intake showed a quadratic effect $(\mathrm{P}<0.05)$ with the increasing levels of replacement. These results are in agreement with those obtained by Allam et al. (2011) who decided that using dried orange pulp as alternative energy source by $50 \%$ replecment corn grains with soybean meal as a protein source to obtained higher performance with lowest cost of feeding. The best feed conversion (Table 7) was that for lambs fed R3. The improvement of feed conversion may be due to improvement in both nutrient digestibilities and nutritive value. In agreement with present results Omer and Tawila (2009) concluded that replacements of corn grains by citrus byproduction in goat ration improved feed efficiency and decreased daily feeding cost and consequently improved relative economic efficiency. similarly, Allam et al. (2011) found that all rations contented dried orange pulp 
(DOP) recorded the best feed conversion values in compression with control one that free from DOP with growing lambs.

Table (7): Effect of experimental rations on growth performance of lambs

\begin{tabular}{|c|c|c|c|}
\hline \multirow[t]{2}{*}{ Item } & \multicolumn{3}{|c|}{ Experimental ration } \\
\hline & $\mathrm{R} 1$ & $\mathrm{R} 2$ & R3 \\
\hline Initial live body weight (I.B.W), Kg & 20.2 & 20.5 & 20.3 \\
\hline Final live body weight (F.B.W), Kg & 42 & 45 & 47 \\
\hline Total body gain, $\mathrm{Kg}$ & 22.2 & 24.5 & 26.7 \\
\hline Daily gain, $g$ & 185 & 204 & 222 \\
\hline \multicolumn{4}{|l|}{ Feed intake/day (DMI), g: } \\
\hline CFM & 650 & 675 & 700 \\
\hline CS & 525 & 270 & - \\
\hline OS & - & 275 & 550 \\
\hline RS & 125 & 130 & 135 \\
\hline Total DM, g & 1300 & 1350 & 1385 \\
\hline Feed conversion (DMI Kg/Kg gain) & 7.03 & 6.61 & 6.24 \\
\hline \multicolumn{4}{|l|}{ Economic Efficiency } \\
\hline Price of daily gain, LE & 11.1 & 12.24 & 13.32 \\
\hline \multicolumn{4}{|l|}{ Daily feed cost, LE:* } \\
\hline CFM & 3.29 & 3.42 & 3.51 \\
\hline $\mathrm{CS}$ & 1.33 & 0.68 & - \\
\hline OS & - & 0.38 & 0.70 \\
\hline RS & 0.05 & 0.05 & 0.06 \\
\hline Total daily feed cost, LE & 4.68 & 4.55 & 4.31 \\
\hline Feed cost $/ \mathrm{kg}$ gain, LE & 42.16 & 37.17 & 32.35 \\
\hline Daily profit, LE & 11.10 & 12.24 & 13.32 \\
\hline Economic feed efficiency, $\% * *$ & 237.2 & 269.0 & 309.0 \\
\hline Relative feed cost, $\% * * *$ & 100 & 88.16 & 76.73 \\
\hline Relative daily profit, $\% * * * *$ & 100 & 110.27 & 120.00 \\
\hline \multicolumn{4}{|c|}{$\begin{array}{l}\text { Price of } 1 \text { ton CFM=4500 LE Price of } 1 \text { ton CS }=900 \mathrm{LE} ; \text { Price of } \\
\text { Market price of } 1 \mathrm{~kg} \text { live body weight in }(2019)=60 \mathrm{LE} . \\
* \text { Daily feed cost calculated as fresh feed }(\text { as fed }) . \\
* * \text { Economic feed efficiency\% } \% \text { daily profit/daily feed cost X } 100 \\
* * * \text { Relative feed cost, } \%=F e e d \text { cost, LE/kg gain }(R 2 \text { and } R 3) / R 1 \\
* * * \text { Relative daily profit, } \%=\text { Daily profit LE }(R 2 \text { and } R 3) / R 1 .\end{array}$} \\
\hline
\end{tabular}

\section{CONCLUSION}

It could be concluded that incorporation of replacement corn silage by orange waste silage in lambs rations improve digestibility, nutritive value and performance of growing lambs meanwhile, solving the problem of environmental pollution ofreplacement $100 \%$ corn silage by orange waste silage (R3) showed the best results.

\section{REFERENCES}

Abou-Akkada, A. R. and Osman H. E. (1967). Studies on the utilization of non protein nitrogen in Egypt. J. Agric. Sci., 169: 25-33.

Allam, S. M.; G.A. Abou-Ward; M. A. Tawila; M. A. Ali; .K. Alsayed and S.I. El-Naggar (2011). Nutritional and economic impact of using dried citrus pulp as energy source in growing lams rations. Egyptian J. Nutrition and Feeds. 14(3):337-347. 
AOAC. (1995). Official Methods of Analysis. $15^{\text {th }}$ Ed. Association of Official Analytical Chemists, Arlington, Virginia, USA.

Armstrong, W. D. and C. W. Carr (1964). Physiological. Chemistry 3rd ed. pp., 75 Burges Publishing CO.Minneapolis, Minnesota, USA.

Ben- Ghedalia, D.; E. Yosef; J .Miron and Y. Est (1989). The effects of starch and pectin -rich diets on quantitative aspects of digestion sheep. Animal Feed Sci. and techhhnol., 24, 289- 298.

Bergen, W. G.; E. H. Cach and H. E. Henderson (1974). Changes in nitrogenous compounds of the whole corn plant during ensiling and subsequent effects on dry matter intake by sheep. J. Animals. Sci., 39:629.

Bueno, M. S., Jr. E. Ferrari, D. Bianchini, F. F. Leinz and C. F. Rodriques (2002). Effect of replacing corn with dehydrated citrus pulp in diets of growing kids. Small Ruminants. Res, 46: 179-185

Conway, E.F. and E. O'Mally (1957). Micro diffusion methods. Ammonia and urea using buffered absorbents. Biochem. J., 36: 655.

Difco, M. (1984). Dehydrated Culture Media Regents for Microbiology, $10^{\text {th }}$ edition, Difco Laboratories Incorporated Detroit, Michigan, USA. pp. 689-691.

Doumas, B. T.; W. A. Wastson and H. G. Biggs (1971). Albumin standards and the measurement of serum albumin with bromocresol green. Clin. Chem. Acta., 31:87-90.

Duncan, D. B. (1955). Multiple Range F Test. Biometrics, 11:1- 42.

Etman, K. E. I.; G. F. Shahin; A. A. El-Tahan and S. K. Sayed (2007). Studies on feeding allowances during different growth periods for crossed Friesian heifers. Egyptian J. Nutrition and Feeds 9 (2): 19-35.

Fassati, P and L. Prenciple (1982). Colorimetric of determination of cholesterol. Clin. Chem., 28.2077.

Folin, O.Z. (1994). Colorimetric of determination of plasma cereatinine. Phys. Chem. 268: 228.

Gado, H.M.; A.Z.M .Salem and N.E. Borhami (2011). Effect of exogenous enzymes ensiled with orange pulp on digestion, blood metabolites and growth performance in lambs. Anim. Feed Sci. Tech. 165, 131 136.

Gawad, AA; A.E.M. Mahmoud and Y.H. Al Slibi (2013). Response of growing bulls fed ration containing different levels of citrus pulp. World Appl. Sci. J. 28(10):1475-1480.

Gholizadeh, H. and A.A. Naserian. (2010). The effects of replacing dried citrus pulp with barley grain on the performance of Iranian Saanen kids. J. Anim. And Vet. Adv.,15: 2053-2056.

Grasse, L.A.; J.G. Fadel; I. Garnett and E.J. DePeters (1995). Quality and economic importance of nine selected by-products used in California dairy rations. J. dairy Sci., 78, 962-971.

Iconomou, D.; K. Kandylis; C. Israilides and P. Nikokyris (1997). Protein enhancement of sugar beet pulp by fermentation and estimation degradability in the rumen of sheep. Small Ruminant Res., 27: 55.

Kleczkowski, M.; W. Klucinski; J. Sikora and M. Zdanowicz (2004). Role of antioxidants in protection against oxidative stress in cattle-trace elements and enzymatic mechanisms (Part 3). Pol. J. Vet. Sci., 7(3): 233-240.

Lanza, A. (1984). Dried citrus pulp in animal feeding. In: Holl'o, J. (Ed.), Proceedings of the International Symposium on Food Industries and the Environment. Budapest, Hungary. Elsevier Pulishers, New York, NY, USA, pp.189-198.

McDonald, P.; R.A. Edwards and J. F. D. Greenholgh (1995). Animal Nutrition (5 $5^{\text {th }}$ edition). Oliver and Boyd Publisher.

Mostafa, M. R. M.; S.B. Mehany; Safaa, N. Abd EL-Azim and Soheir, J. Latif (2010). Effect of using three varieties of sorghum bicolor stover silages on performance of growing and fattening lambs. Egyptian J. Nutrition and Feeds, 13 (2): 271-283.

NRC. (1985). Nutrient Requirements of Domestic Animals Nutrient Requirements of Sheep $5^{\text {th }}$ Ed. National Academy of sciences- National Research council, Washington D. C. , USA 


\section{Mahrous et al.}

Omer, H.A.A. and M.A. Tawila (2009).Response of baladi goats to diets containing different levels of citurs by product. Egypt. J. Nutr. and Feeds, 12(1): 75- 88.

Phillip, Y. L.; A. A. Mahrous; A. A. Khir and Safa N. Abdel-Azeem (2014). Productive performance of small ruminants fed pruning fruits trees by products. 1. Effect of treated pruning grape trees by-products on growing Ossimi lambs. Egyptian J. Nutrition and Feeds (2014), 17 (3): 409-421.

Qelurem, O. I.; A.G. Ngi and I.A. Andrew (2007). Phtonutrients in citrus fruit peel meal and nutritional implaction for livectock production. LRRD. Eprints. Kfupm, edu.sa/ view /year/ 2007.htmi.

Reitman, S. and S. Frankel (1957).Colorimetric determination of GPT activity according to the Reitman and Frankel method.Am.J.clim.path.28- 56.

Richmond, W. (1973).Clin. Chem., 19, 1350.SAS (2009). Statistical Analysis System. SAS Institute, version 9.2. Cary, NC, USA.

SAS (2004). SAS/STAT 9.1.3 User's Guide: Statistical Analysis System Institute Inc., Cary, NC, USA.

Shaver, R. D.; R. A. Erdman; A. M. O'connor and J. H. Vandersall (1985). Effects of silage pH on voluntary intake of corn silage and alfalfa haylage. J. Dairy Sci., 68: 338

Shdaifat, M. M.; F. S .Al-Baraka; A.Q. Kanana and B.S. Obeidatb (2013). The effect of feeding agricultural by-products on performance of lactating Awass ewe. Small Ruminan Research.113:11-14.

Sheperd, A. C. and L. Kung (1996). Effect of enzyme additives on composition of corn silage ensiled at various stages of maturity. J. Dairy Sci., 79: 1767.

Shoukry, M.M.; H.S. Soliman; H.M. Ali and F.I.S. Hilal (1986). In vitro and In situo evaluation of some solar dehydrated vegetable and fruits by-products as feed sources for ruminants. The $4^{\text {th }}$ congress of animal feeding. Madried-Spain, 30 June-4 July, 1986.

Shultz, T. A. and E. Shultz (1970). Estimation of rumen microbial nitrogen by three analytical methods. J. of Dairy Sci., 53 : $781-784$.

Sies, H. (1997). Oxidative stress: oxidants and antioxidants. Exp. Physiol., 82(2), 291-295.

Siest, G.; J. Henny and F. Schiele (1981). Interpretion des examens de laboratories , karger Ed., P. 206.

Snedecor, W. and W. Cochran (1980). Statistical Methods. Iowa State University Press, Ames Iowa, seventh edition.

Sun, Z. H.; S. M. Liu; G. O. Tayo and S. X. Tang (2009). Effects of cellulose or lactic acid bacteria on silage fermentation and in vitro gag production of several morphological fractions of maize stover. Anim. Feed Sci. and Tech v, 152, p 219-231.

Taie, H.T.; M. M. Abd El-Rahman; B.M. Ahmed and S. M. Awara (1998). Effect of dietary energy on digestibility, rumen fermentation, gestation kinetics, performance and carcass traits of sheep. First International Conference on Animal Production and Health in Semi-Arid Areas, 1-3 September PP. 134, El-Arish North Sinai, Egypt.

Van Soest, P. J.; J.D.Robertson and B. A. Lewis (1991).Methods for dietary fibre, neutral detergent fiber and non-starch polysaccharides I n relation to animal nutrition . Journal of Dairy Science,74:3583.

Warner, A. C. I. (1964). Production of volatile fatty acids in the rumen, methods of measurements. Nutr. abstr. and Rev., 34: 339. 


\section{احلال سيلاج الذرة بسيلاج مخلفات البرتقال فى علائق حملان الاغنام البرقى}

\section{احمد عبد الرحمن محروس1 و ايمن سعيد كركوتلى 2 وعلاء الدين احمد حسن الطحان 1 و يوسف حسين حافظ1}

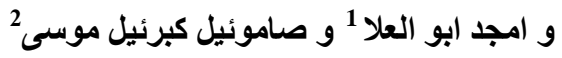

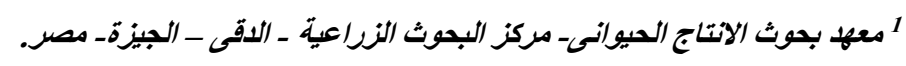
2/المركز العربى لدراسات المناطق الجافة والاراضى القاطة ـ اكساد ـ دمثق - سوريا.

الاوريت هذة الدراسة لتقييم احلال سيلاج مخلفات البرتقال محل سيلاج الذرة على الاداء الانتاجي للحملان البرقى وتم اجراء تجاء تجربتين:

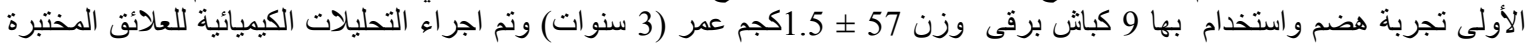

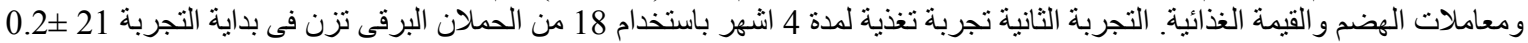

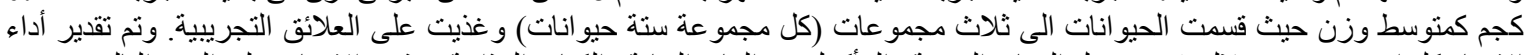

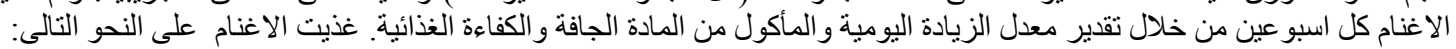

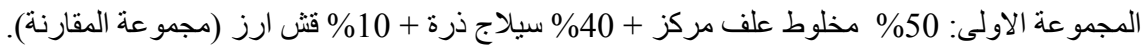

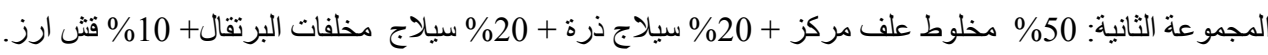

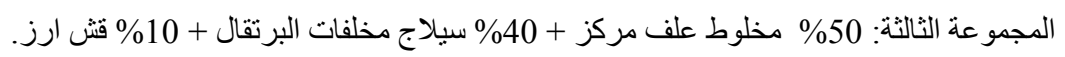

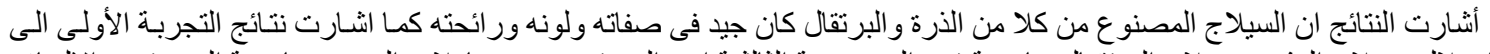

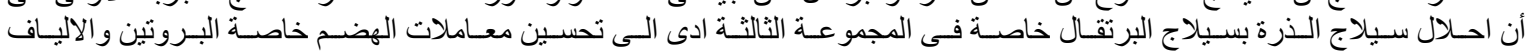

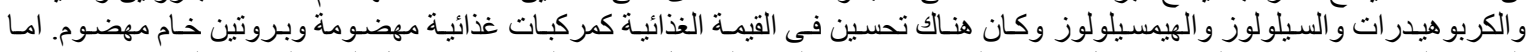

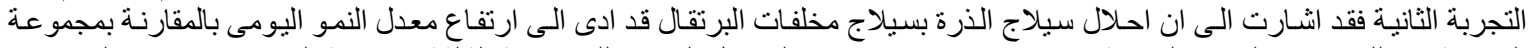

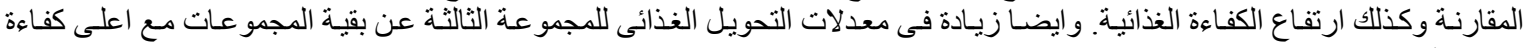

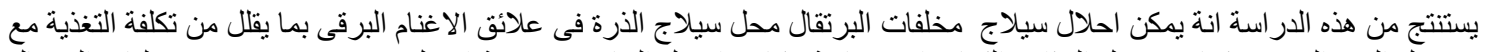

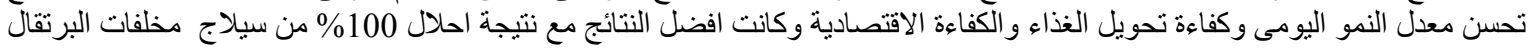
بسيلاج الذرة تحت الظروف المصرية. 